\title{
Variability of UTCI index in South Warsaw depending on atmospheric circulation
}

\author{
Katarzyna Rozbicka ${ }^{1}$ - Tomasz Rozbicki ${ }^{1}$
}

Received: 13 October 2016 / Accepted: 8 June 2017 / Published online: 28 June 2017

(C) The Author(s) 2017. This article is an open access publication

\begin{abstract}
The aim of the study is the assessment and analysis of the variability of human-bioclimatic conditions in southern part of Warsaw, depending on the atmospheric circulation in the long-term (1998-2015). The Universal Thermal Climate Index UTCI was applied to evaluate the human-bioclimatic conditions using meteorological data for the 12:00 UTC obtained from the WULS Ursynów weather station. In order to determine the relationship between the UTCI and its corresponding synoptic situation, the circulation type classification proposed by Lityński was used. It was found that the period from the second decade of April to the first decade of October is the most favourable one for recreation and relaxation. The situations not caused by thermal loads of humans are the most frequent and the values vary from $42.9 \%$ in October to $66.6 \%$ in August. Whereas weather conditions causing the 'strong' and 'very strong heat stresses' and the 'strong' and 'very strong cold stresses' were relatively rare. The analysis of influence of atmospheric circulation on bioclimatic conditions has shown that the most favourable conditions with no heat load (class 0 ) of the body occurred during cyclonic circulation in the summer $(70 \%)$ mainly at advection from the North and South. Particular analysis of selected most strenuous days of the heat wave and the cold wave confirmed the occurrence of a high frequency of conditions stressing the human body with
\end{abstract}

Katarzyna Rozbicka

katarzyna_rozbicka@sggw.pl

Tomasz Rozbicki

tomasz_rozbicki@sggw.pl

1 Division of Meteorology and Climatology, Department of Hydraulics Engineering, Warsaw University of Life Sciences-SGGW, Nowoursynowska 159, 02-776 Warsaw, Poland 'strong' and 'very strong heat' as well as 'strong cold' for most of the day during anticyclonic circulation in both cases.

Keywords Universal Thermal Climate Index (UTCI) . Atmospheric circulation · Warsaw

\section{Introduction}

There are a few dozen different indices describing the influence of atmospheric environment on the human body. However, most of them lack a direct link with physiological reactions which occur in the body in response to the prevailing thermal conditions. In the 1990s, so-called multi-node models of human heat balance were developed to describe all mechanisms of thermoregulation. One of those models provided the basis for the development of a thermal index (UTCI Universal Thermal Climate Index), whose purpose is to evaluate the degree of thermal stress the human body is exposed to. The UTCI is assumed to provide information of thermal and physiological processes across the entire spectrum of possible environmental conditions (considering the seasonality of climate) and in all spatial scales. The index should be useful for key applications in human bioclimatology, as well as climatotherapy.

Bioclimatic conditions, mainly in cities or attractive touristic places, have been described using not only the UTCI index but also other indices (e.g. Physiological Equivalent Temperature (PET), Effective Temperature (ET), Physiological Subjective Temperature (PST), Heat Index (HI), Apparent Temperature (AT) in quite a number of studies in Poland and abroad). Among other, Blażejczyk et al. (2012) compared selected thermal indices with UTCI index, Kuchcik et al. (2013) published one of few works which attempt to investigate various bioclimatological aspects in the whole area 
of Poland, including the capital city of Warsaw. There are also studies in which bioclimatic conditions in Warsaw are analysed, such as one of the authors of the UTCI: Błażejczyk and Błażejczyk (2014), Błażejczyk et al. (2010, 2013, 2014) and Lindner (2011). Other cities are the subject of the works of Mąkosza (2013), who studied bioclimatic conditions in the Lubuskie province and in Szczecin by Czarnecka et al. (2011) and Nidzgorska-Lencewicz, Mąkosza (2013), the analysis was based on UTCI and ET (Effective Temperature) indices. Okoniewska and Więcław (2013), who conducted observations of bioclimatic conditions in Kołobrzeg, Poznań and Szczawno, and Chabior (2011) who focused on the bioclimate of Szczecin, Kołobrzeg and Chojnice. On the other hand, studies into the relationship between bioclimatic conditions and atmospheric circulation, such as those published by Bryś and Ojrzyńska (2016) for Wrocław, Nowosad et al. (2013) for Lublin and Lesko and Kotas et al. (2013) are relatively scarce. There are also works which deal with different connections between the UTCI and human mortality, e.g. Idzikowska (2011), or the quality of air, e.g. Nidzgorska-Lencewicz (2015), who studied the relationship between the UTCI and the quality of urban air, analysing selected air pollutants in Gdańsk. Czarnecka and NidzgorskaLencewicz (2014) studied the intensity of urban heat island connected with air pollution during the 2010 Heat Wave in Gdańsk. The quality of air in Warsaw is the subject of such works as Rozbicka et al. (2014), Rozbicka and Rozbicki (2016a, b) and Majewski et al. (2014) where biometeorological conditions were also studied.

As far as international studies of bioclimatic conditions are concerned, the UTCI has been applied in numerous aspects. Bröde et al. (2012a), for instance, analysed the bioclimate of South Brazil, Nemeth (2011) studied seasonal and spatial variability of bioclimatic conditions in Hungary, Błażejczyk et al. (2010) and Błażejczyk and Błażejczyk (2014) studied the bioclimate of a few European cities, whereas Bleta et al. (2014) dealt with the bioclimatic conditions on Crete (Greece). A number of researchers have been looking for connections between bioclimatic conditions and mortality, often related to heat waves or focused on their separate analysis; Kyselỳ (2002, 2004), Makrogiannis et al. (2008), Matzarakis and Nastos (2011), Idzikowska (2011), Ndetto and Matzarakis (2015), Basarin et al. (2016); or between bioclimatic conditions and air pollution and pollen, Jacobs et al. (2014), Ndetto and Matzarakis (2015). On the other hand, Quansheng et al. (2016), Matzarakis (2014), Matzarakis et al. (2013), Zaninović and Matzarakis (2009), Lin and Matzarakis (2008) studied the climate from the point of view of tourism development prospects and Fröhlich and Matzarakis (2015) analysed the limitations and shortcomings of the three indices (PT, UTCI, PET) under the hot and windy meteorological conditions observed in Doha, Qatar. The research explored the role of street trees in Melbourne, Australia, in cooling the urban microclimate and improving human thermal comfort (HTC) were calculated using the UTCI index given by Coutts et al. (2016) and Walikewitz et al. (2015) which made an assessment of indoor heat stress variability in summer and during heat warnings in Berlin, Germany.

In summary there is a lot of works both in Poland and abroad, studying the variability of human-bioclimatic conditions in various aspects. The present approach to the variations of thermal loads calculated on the basis of a relatively new indicator UTCI under the influence of atmospheric circulation was previously considered by few researchers. Atmospheric circulation is one of the most important dynamic factors forming the weather and climatic conditions in the relevant area. This is the reason why the results of this study may contribute to a better understanding of the impact types of atmospheric circulation on human thermal comfort especially in the most unfavourable ones in the big city. The Warsaw agglomeration with about 2.7 million citizens is the second the most popular city destination in Poland, visited by above 8 million visitors every year (analysis on Report on tourism visitors to Warsaw 2016 given in www.um.warszawa.pl) and third posistion. Because Warsaw is a significant city both for locals and tourists and the results may also be used as an important information to domestic and also to tourists, tourism authorities, the tourism industry and development of tourism destinations.

\section{Data and methods}

The long-term (1998-2015) variability of perceived climate conditions in South Warsaw was analysed using meteorological data for 12:00 UTC obtained from the WULS Ursynów weather station - Laboratory Water Center (Fig. 1): air temperature $\left({ }^{\circ} \mathrm{C}\right)$, relative humidity of air $(\%)$, wind speed $\left(\mathrm{m} \mathrm{s}^{-1}\right)$ at a height of $10 \mathrm{~m}$ a.g.l. and cloudiness data were sourced from the Warsaw Okęcie station. The types of circulation were

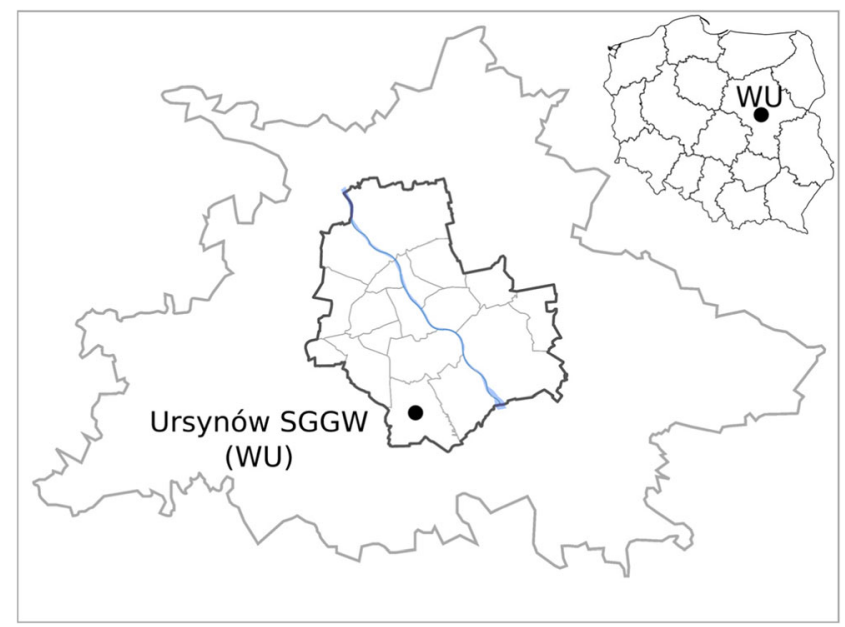

Fig. 1 Location of meteorological station-Warsaw-Ursynów SGGW (WU) 
determined according to the criteria by Lityński (1969) and Pianko-Kluczyńska (2007). The classification comprises three elements specified on surface synoptic charts: the zonal circulation index, the meridional circulation index, both determined for the area situated at $\varphi 40-65^{\circ} \mathrm{N}, \lambda 0-35^{\circ} \mathrm{E}$ and the value of atmospheric pressure in Warsaw. The values of each of these three parameters were assigned to three equiprobable classes (anticyclonic circulation, cyclonic circulation and neutral), which gave 27 circulation types in total (Szyga-Pluta 2009). The atmospheric circulation data were provided by the Institute of Meteorology and Water Management in Warsaw.

The WULS Ursynów station $\left(\phi=52^{\circ} 09^{\prime} \mathrm{N}, \lambda=21^{\circ} 03^{\prime} \mathrm{E}\right.$, $H_{\mathrm{S}}=102.5 \mathrm{~m}$ a.s.l.) is situated in Ursynów, a southern district of Warsaw, on the outskirts of the city and at the WULS campus, $9 \mathrm{~km}$ from the city centre. The station is surrounded by flat land, dotted with predominantly single-storey buildings, located at a distance of 150-300 m away. Further away, on the other hand, there is an area densely developed with high buildings, situated between $400 \mathrm{~m}$ and $2 \mathrm{~km}$ from the station. The Vistula River valley slope stretches to the north-west.

\subsection{The Universal Thermal Climate Index}

The UTCI is based on Fiala's multi-node thermoregulation model (Fiala et al. 2012) which is coupled with an advanced clothing model (Havenith et al. 2012) that takes into account the effects of air temperature on behaviour adaptation of clothing insulation of the general public. The UTCI was derived conceptually as an equivalent temperature. That is, for any combination of air temperature $\left(T_{\mathrm{a}},{ }^{\circ} \mathrm{C}\right), 10-\mathrm{m}$ wind speed $(v$, $\left.\mathrm{m} \mathrm{s}^{-1}\right)$, vapour pressure $(e, \mathrm{hPa})$ and mean radiant temperature $\left(T_{\mathrm{mrt}},{ }^{\circ} \mathrm{C}\right)$, which together represent the thermal stress of the actual environment, the UTCI is defined as the air temperature that would cause the same dynamic physiological response (strain) under a set of reference conditions. These reference conditions include a walking speed of $4 \mathrm{~km} / \mathrm{h}$ (equivalent to a metabolic rate of $2.3 \mathrm{MET}=135 \mathrm{~W} \mathrm{~m}^{-2}$ ), a 10-m wind speed of $0.5 \mathrm{~m} \mathrm{~s}^{-1}, T_{\mathrm{mrt}}$ equal to $T_{\mathrm{a}}$, relative humidity (rH) of $50 \%$ for $T_{\mathrm{a}}<29^{\circ} \mathrm{C}$ and vapour pressure of $20 \mathrm{hPa}$ for $T_{\mathrm{a}}>29^{\circ} \mathrm{C}$ (Bröde et al. 2012b). The thermal stress assessment scale (Table 1) was derived from the modelled physiological and psychological response (Fiala et al. 2012). Calculating the UTCI by repeatedly running the thermoregulation model is computationally intensive and thus too time-consuming for climate simulations and numerical weather forecasts. Therefore, a rapid calculation using a polynomial approximation procedure was developed. The offset of UTCI to $T_{\mathrm{a}}$ (UTCI- $T_{\mathrm{a}}$ ) can be approximated by a polynomial function including $T_{\mathrm{a}}, v, e$, and $T_{\mathrm{mrt}}-T_{\mathrm{a}}$, with all main effects and interactions terms up to the sixth order (Eq. 1) (Bröde et al., 2012b).

$$
U T C I-T_{\mathrm{a}}=f\left(T \mathrm{a}, v ; e, \pm T_{\mathrm{mrt}}-T_{\mathrm{a}}\right)
$$

Table 1 Assessment scale of UTCI (Fiala et al. 2012, Havenith et al. 2012)

\begin{tabular}{ccl}
\hline UTCI $\left({ }^{\circ} \mathrm{C}\right)$ & Number & Heat stress classes \\
\hline above +46.0 & 4 & Extreme heat stress \\
+38.1 to +46.0 & 3 & Very strong heat stress \\
+32.1 to 38.0 & 2 & Strong heat stress \\
+26.1 to +32.0 & 1 & Moderate heat stress \\
+9.1 to 26.0 & 0 & No thermal stress \\
0.1 to +9.0 & -1 & Slight cold stress \\
-12.9 to 0.0 & -2 & Moderate cold stress \\
-27.0 to -13.0 & -3 & Strong cold stress \\
-39.9 to -27.0 & -4 & Very strong cold stress \\
below -40.0 & -5 & Extreme cold stress \\
\hline
\end{tabular}

Both mean radiant temperature $\left(T_{\mathrm{mrt}}\right)$ and UTCI were calculated with the use of the BioKlima 2.6 software package (available at http://www.igipz.pan.pl/Bioklima-zgik.html). In this paper, data set includes 6576 data. About $2.5 \%$ cases are the values of wind velocity less than $0.5 \mathrm{~m} \mathrm{~s}^{-1}$ and about $0.1 \%$ cases are the values of air temperature greater and equal than $29.0{ }^{\circ} \mathrm{C}$. These cases were included to the research. The value of the UTCI can provide the basis for assessment of thermal stress the human body is exposed to (Table 1).

\subsection{Approach for analysis in Warsaw}

In this study, thermal comfort is analysed using UTCI (Universal Thermal Climate Index) values for Warsaw, and the resultant human-biometeorological classes are combined with the atmospheric circulation types in seasons. The frequencies of extreme thermal comfort conditions for types of atmospheric circulations are to offer an important information of local climate for citizen and tourism demand.

\section{Results and discussion}

\subsection{Seasonal variation and incidence of the UTCI index}

The mean annual value of UTCI ranged from $3.5^{\circ} \mathrm{C}$ in 1998 to $9.3{ }^{\circ} \mathrm{C}$ in 2007 and reached $6.9{ }^{\circ} \mathrm{C}$ for the whole period under consideration, i.e. the years 1998-2015 (Table 2). This corresponds to the conditions from 'moderate cold stress' to 'no thermal stress'. Similar results were obtained by Kuchcik et al. (2013) for the central region of Poland (representing four stations, including Warsaw, in the years $1991-2000)-6.5^{\circ} \mathrm{C}$, Makosza (2013) for Lubuskie province-from $6.1^{\circ} \mathrm{C}$ in Zielona Góra and Gorzów Wielkopolski to $8.8^{\circ} \mathrm{C}$ in Słubice, whereas the mean annual UTCI obtained for 
Table 2 Mean monthly and annual values with standard deviation (SD) of the UTCI index in particular years, 1998-2015 Warsaw-Ursynów

\begin{tabular}{|c|c|c|c|c|c|c|c|c|c|c|c|c|c|}
\hline $\begin{array}{l}\text { Months } \\
\text { Years }\end{array}$ & I & II & III & IV & V & VI & VII & VIII & IX & $X$ & XI & XII & I-XII \\
\hline 1998 & -4.8 & -5.7 & -3.9 & 6.6 & 12.6 & 16.7 & 15.7 & 14.4 & 12.0 & 1.9 & -11.0 & -12.1 & 3.5 \\
\hline 1999 & -8.8 & -11.1 & 0.1 & 5.7 & 9.8 & 16.0 & 18.8 & 16.4 & 14.5 & 3.3 & -4.5 & -8.3 & 4.3 \\
\hline 2000 & -13.1 & -5.6 & 0.6 & 14.9 & 20.0 & 20.3 & 17.9 & - & - & - & - & -5.2 & 6.2 \\
\hline 2001 & -8.1 & -5.0 & -2.8 & 8.5 & 19.0 & 18.6 & 26.0 & 25.3 & 12.2 & 12.0 & -6.6 & -15.1 & 7.0 \\
\hline 2002 & -8.9 & -5.3 & -3.3 & 8.6 & 23.7 & 20.6 & 24.7 & 27.9 & 14.4 & 2.8 & -0.8 & -14.1 & 7.5 \\
\hline 2003 & -11.3 & -8.5 & -0.1 & 5.3 & 20.2 & 22.6 & 25.7 & 22.1 & 19.9 & 3.5 & 1.2 & -8.1 & 7.7 \\
\hline 2004 & -11.9 & -7.9 & -1.6 & 10.4 & 13.0 & 17.1 & 21.6 & 23.5 & 15.5 & 10.1 & -4.7 & -8.2 & 6.4 \\
\hline 2005 & -11.5 & -9.6 & -5.5 & 13.3 & 16.6 & 18.2 & 26.1 & 23.3 & 22.4 & 11.0 & 2.2 & -8.1 & 8.2 \\
\hline 2006 & -6.1 & -3.7 & 1.9 & 10.2 & 4.9 & 23.4 & 23.0 & 20.1 & 18.6 & 8.2 & 2.6 & -1.3 & 8.5 \\
\hline 2007 & -0.8 & -2.4 & 4.9 & 10.0 & 18.4 & 21.3 & 19.3 & 22.2 & 14.2 & 8.3 & -0.9 & -2.7 & 9.3 \\
\hline 2008 & 0.7 & -0.6 & -8.0 & 3.4 & 10.5 & 23.7 & 22.8 & 20.3 & 13.4 & 9.6 & -3.4 & -6.4 & 7.2 \\
\hline 2009 & 0.7 & -0.4 & -8.5 & 3.2 & 10.0 & 23.6 & 22.8 & 20.7 & 13.9 & 9.5 & -3.2 & -6.6 & 7.2 \\
\hline 2010 & -12.0 & -9.1 & -5.5 & 16.7 & 15.2 & 16.4 & 24.1 & 22.6 & 20.5 & 4.3 & 0.0 & -9.6 & 7.0 \\
\hline 2011 & -11.5 & -13.9 & -0.9 & 11.8 & 17.2 & 21.5 & 20.1 & 23.4 & 17.3 & 6.5 & -1.6 & -8.1 & 6.8 \\
\hline 2012 & -14.1 & -13.8 & -1.6 & 6.6 & 15.8 & 17.9 & 24.9 & 22.2 & 15.4 & 7.5 & -1.0 & -13.4 & 5.6 \\
\hline 2013 & -14.0 & -10.2 & -10.2 & 5.5 & 16.4 & 22.7 & 24.0 & 23.8 & 12.4 & 10.2 & -1.4 & -8.0 & 5.9 \\
\hline 2014 & -15.1 & -2.1 & 4.4 & 11.5 & 15.2 & 18.0 & 25.8 & 21.1 & 18.1 & 9.1 & -3.1 & -10.0 & 7.7 \\
\hline 2015 & -10.8 & -5.1 & 0.6 & 4.9 & 14.3 & 20.6 & 23.2 & 29.1 & 15.9 & 5.5 & -2.2 & -4.8 & 7.6 \\
\hline $1998-2015$ & -9.0 & -6.7 & -2.2 & 8.7 & 15.2 & 20.0 & 22.6 & 22.3 & 15.9 & 7.2 & -2.3 & -8.3 & 6.9 \\
\hline $\mathrm{SD}$ & 8.8 & 7.9 & 9.4 & 9.7 & 9.0 & 7.7 & 7.0 & 6.9 & 7.4 & 8.0 & 8.3 & 7.8 & 8.2 \\
\hline
\end{tabular}

Warsaw by Błażejczyk was lower and reached $4.2{ }^{\circ} \mathrm{C}$ in the years 1991-2000.

In the annual course, the lowest values of the index were observed in January and December, which proves the fact that the 2 months caused the most thermal stress for the human body, even around midday. The lowest mean value in January was $-9.0^{\circ} \mathrm{C}$, which is equivalent to a moderate cold stress. Minimum values $\left(-42.1{ }^{\circ} \mathrm{C}\right.$ in January and $-36.9{ }^{\circ} \mathrm{C}$ in December) occurred in the winter months from December to February and correspond to a 'very strong cold stress' (category -4 ), indicating that the extremities and face should be protected against cooling and physical activity should be intensified (Table 2). A similar value for Warsaw in the period $1991-2000,-38.3^{\circ} \mathrm{C}$ (in January), was obtained by Kuchcik et al. (2013), whereas Mąkosza (2013) and Błażejczyk and Błażejczyk (2014) obtained much lower absolute lowest values of the UTCI, $-54.8^{\circ} \mathrm{C}$ in Gorzów Wielkopolski in December (Mąkosza 2013) and $-51.9{ }^{\circ} \mathrm{C}$ in Warsaw (Błażejczyk and Błażejczyk 2014), both corresponding to an 'extreme cold stress' condition (category -4$)$. In other analysed places, Słubice and Zielona Góra (Mąkosza 2013), on the other hand, the obtained values were substantially higher and thus closer to those obtained in Warsaw by Kuchcik et al. (2013), reaching -42.9 to $-34.1{ }^{\circ} \mathrm{C}$ (December) and -40.8 to $-38.3{ }^{\circ} \mathrm{C}$ (January), respectively. The standard deviation ranged from 6.9 (August) to 9.7
(April) and the mean value for the whole period of 19982015 reached 8.2 (Table 2).

The month with the highest mean monthly value of UTCI was August, when $29.1{ }^{\circ} \mathrm{C}$ was recorded in 2015 and $27.9^{\circ} \mathrm{C}$ in 2002, both corresponding to a 'moderate heat stress' (category 1). On the other hand, the highest mean monthly value of the whole period, $22.6{ }^{\circ} \mathrm{C}$, was observed in July, when no thermal stress is generally encountered and thermoregulation processes are enough to maintain thermal comfort. A similar range of UTCI for the years 2000-2009 in Warsaw was identified by Lindner (2011), Kuchcik et al. (2013) for Warsaw (22.2 ${ }^{\circ} \mathrm{C}$ in August) and Makosza (2013) for the Lubuskie province (Słubice, Zielona Góra and Gorzów Wielkopolski) in the years 1971-2006. Maximum values were recorded in the summer and their peak occurred in August and reached $39.5^{\circ} \mathrm{C}$, which means a 'very strong heat stress' (category 3 ), when it is necessary to drink to prevent the loss of fluid. For comparison, Błażejczyk and Błażejczyk (2014) obtained the highest value of UTCI of $41.1{ }^{\circ} \mathrm{C}$ for Warsaw in the years 1991-2000; Makosza obtained higher maximum values: $43.1{ }^{\circ} \mathrm{C}$ for Stubice, $41.9{ }^{\circ} \mathrm{C}$ for Gorzów Wielkopolski and $40.4{ }^{\circ} \mathrm{C}$ for Zielona Góra. These values are slightly higher than the $38.8^{\circ} \mathrm{C}$ obtained by Lindner (2011) for the Okecie district of Warsaw in 2000-2009, but comparable to the results for Łódź, worked out by Błażejczyk et al. (2010) (Table 2). 


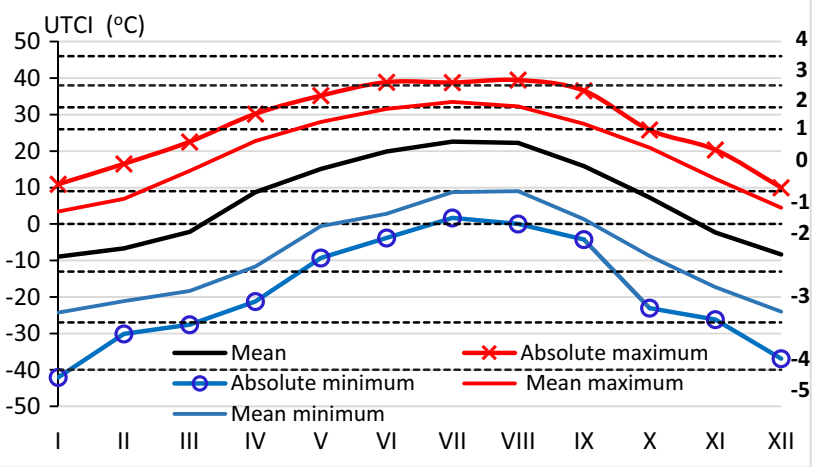

Fig. 2 Annual course of absolute maximum, absolute minimum, mean maximum, mean minimum and mean values of the UTCI index calculated using hourly data at Warsaw-Ursynow, 1998-2015

The obtained values of the UTCI index indicate that the greatest thermal load on human organism due to cold occurred in the last period of the twentieth century, while the greatest thermal load due to heat occurred in the period 2005-2007. The annual course of mean and maximum and minimum (absolute and mean) monthly values of UTCI (Fig. 2) also indicates that the values of UTCI followed substantial fluctuations, revealing the conditions of a very strong cold stress (category -4) from early December until at the beginning of March. The absolute maximum values of the index reached as much as $10{ }^{\circ} \mathrm{C}$ (no thermal stress, category 0 ) and the mean maximum values of index reached as much as $4.4^{\circ} \mathrm{C}$ ('slight cold stress', category -1 ). In the summer months, the temperatures varied across a wide range of values, from $-4{ }^{\circ} \mathrm{C}$ (moderate cold stress) to nearly $40{ }^{\circ} \mathrm{C}$ ('very strong heat stress'). Similar results were obtained at the Okecie station in Warsaw by Błażejczyk and Błażejczyk (2014); the UTCI ranged from $-51.9^{\circ} \mathrm{C}$ (December) to $41.1^{\circ} \mathrm{C}$ (August) in the years $1991-$ 2000; and Lindner (2011), the values ranged from $-40.8{ }^{\circ} \mathrm{C}$ (January) to $38.8^{\circ} \mathrm{C}$ (June) in the years 2000-2009.

In Fig. 3, presenting the frequency of occurrence of the various thermal stresses by seasons, the most favourable conditions, without thermal stress, occur in the summer in $61.0 \%$,

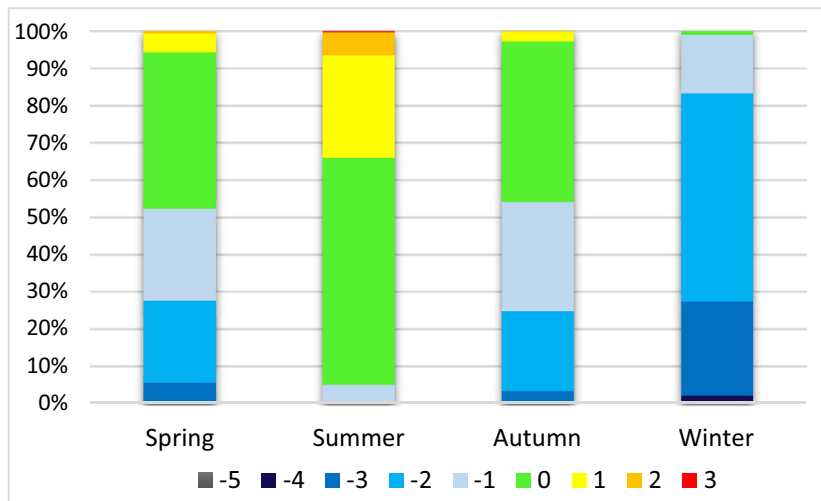

Fig. 3 Frequency of thermal classes in Spring, Summer, Autumn and Winter seasons in Warsaw-Ursynów, 1998-2015 similar in the spring and autumn in 42 and $43.2 \%$, respectively, and in the winter in just $0.9 \%$ of cases. At the same time, summer is the season when $6.1 \%$ of 'strong heat stress' conditions (category 2 ) and $0.3 \%$ of very strong heat conditions (category 3 ) occur, whereas winter is the season when $2.1 \%$ of 'very cold stress' conditions (category -4 ) and $0.1 \%$ of extreme cold stress (category -5 ) conditions occur. Such conditions do not occur in the other seasons.

An analysis of the frequency of occurrence of different thermal stresses in Southern Warsaw shows that during the 7 months of the year (April through September) no thermal stress situations prevail (Category 0 ) and human physiological thermoregulation processes are enough to maintain thermal balance. The values range from $47.4 \%$ in October to $63.5 \%$ in June, and $61.9 \%$ in August, in this category. On the other hand, from November to March, moderate cold stress conditions are the most frequent (category -2 ); they require protection of the face and extremities against cooling and physical activity should be intensified. Their values range from $45 \%$ in March to 59.9\% in December. Weather conditions which cause 'strong' and 'very strong stresses' are less frequent: a 'strong' and very strong cold stress (categories -3 and -4 ) occurs in December through March and ranges from 0.2\% (March) - very strong cold stress - to 28.2\% (January) strong cold stress. The extreme cold stress (category -5 ) is the least frequent and occurs only in January in $0.2 \%$ cases. A strong heat stress is observed from April to September, ranging from 2.9\% (April) to 25.4\% (July and August), and a very strong heat stress (category 3 ) occasionally occurs in the summer (June through August) in only $0.4 \%$ cases (Fig. 4). Similar results were obtained by Lindner (2011), Kuchcik et al. (2013) and Błażejczyk and Błażejczyk (2014).

\subsection{Shaping bioclimatic conditions by atmospheric circulation}

One of the most important climate factors is the constant pressure system patterns over the European continent. Arctic high pressure, Iceland low pressure and Azores islands high-

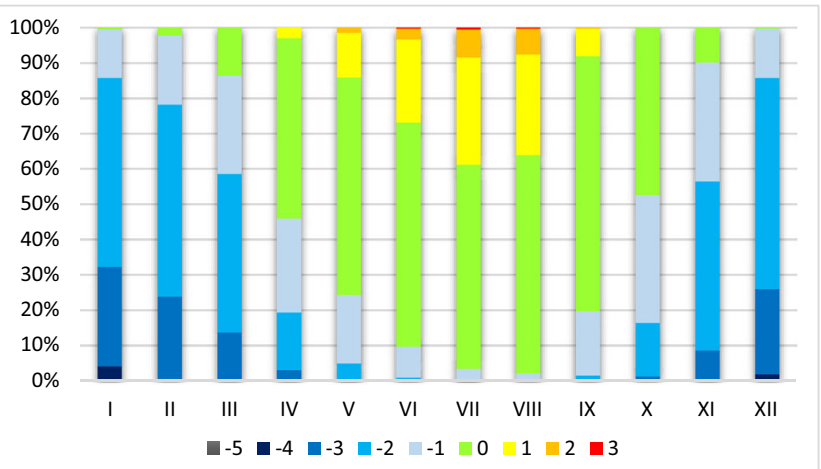

Fig. 4 Frequency of thermal classes in months in Warsaw-Ursynow, 1998-2015 
Fig. 5 The incidence of UTCI classes during atmospheric circulations: anticyclonic (a), intermediate unclassifiable (o) and cyclonic (c) in seasons, Warsaw-Ursynów 1998-2015
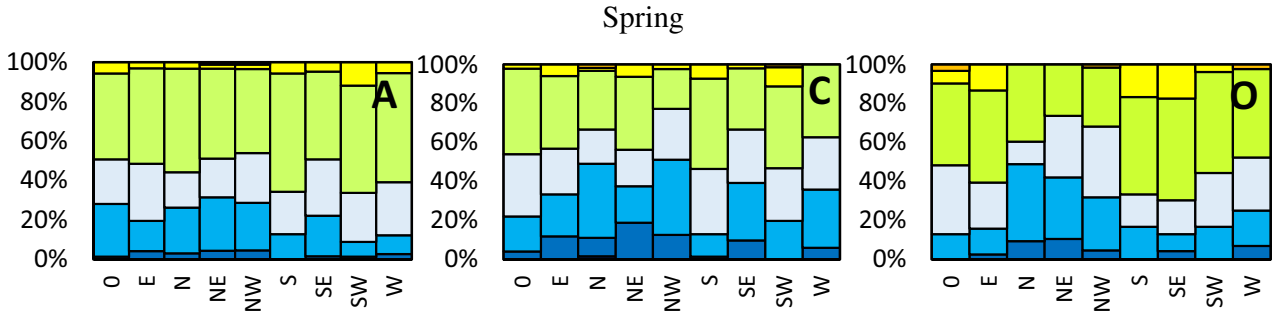

Summer
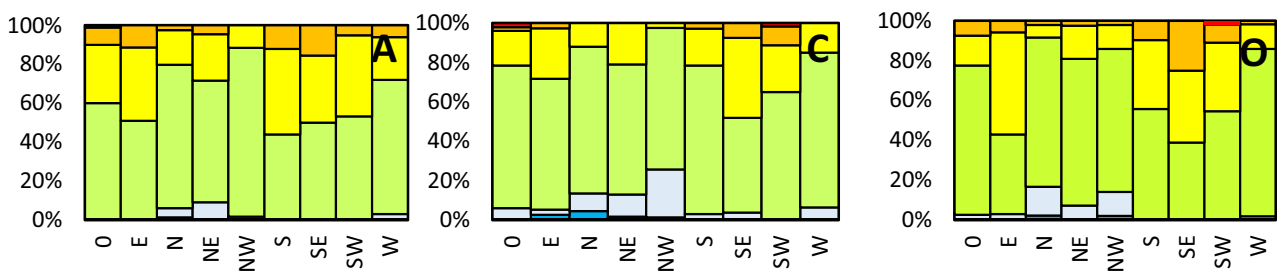

Autumn
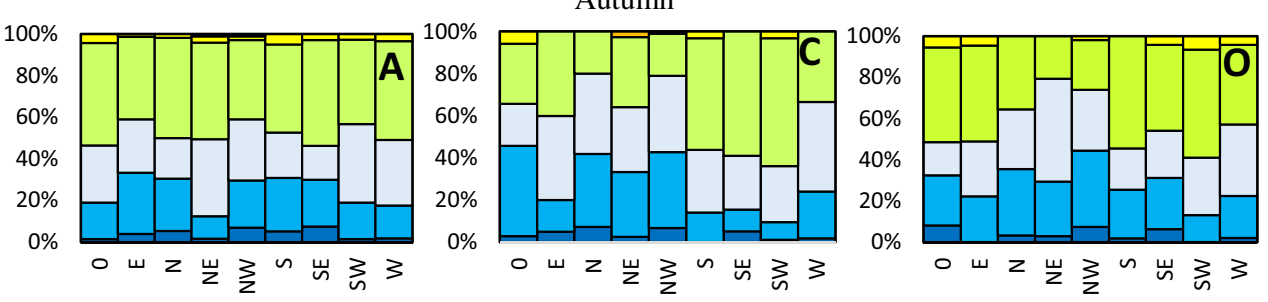

Winter
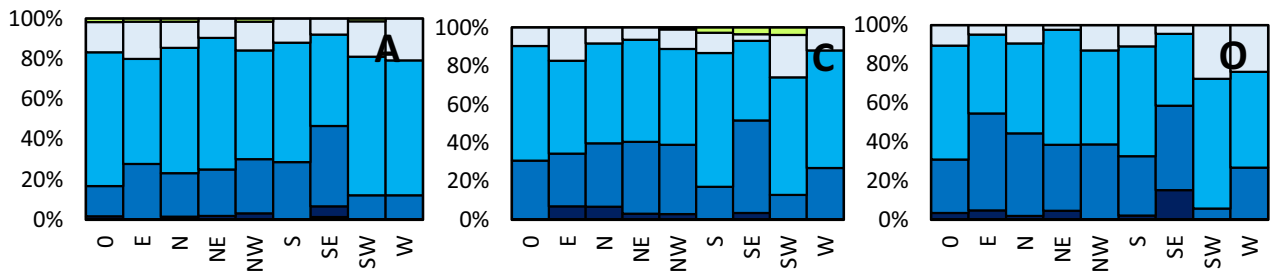

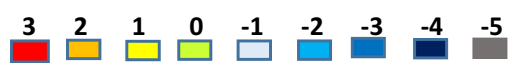

pressure systems and West Siberian high pressure in winter and the West Siberian low-pressure systems in summer. Depending on their location and the force of influence at different seasons, they determine the direction of the air mass inflow. The influence of these factors, i.e. the type of circulation, the mass of air and the direction of mass flow, leads to specific weather conditions, which in turn shaped biometeorological conditions, e.g. human conditions (Błażejczyk 2002).

This section includes the analysed occurrence of particular thermal sensations depending on the type of atmospheric circulation and the direction of advection of air masses, taking into account the seasons (Fig. 5). The most favourable thermal conditions (thermally acceptable) for the human without thermal stressed, slightly stressed or moderately stressed are related to categories from moderate heat stress to moderate cold stress (categories $1,0,-1,-2$, respectively) occurred during the anticyclone circulation in both Spring and Autumn (96\% of cases) but the least favourable in Winter (66\% of cases) during unclassifiable circulation. This results are similar to the statement of Błażejczyk (2002) that the most favourable are the Spring months mainly the second half of April and May and the Autumn months as September and October.

The special attention should be drawn to the situations in which there are strong load of the human body. They contribute to the extreme feeling of thermal conditions, both because of heat stress and cold stress. The highest frequency of cold stress loading, corresponding to categories $-3,-4$ and -5 , i.e. strong cold stress, very strong cold stress and extreme cold stress were observed during the Winter for all types of circulation. The frequency ranged from $25 \%$ during the anticyclone circulation to $34 \%$ during the unclassifiable circulation, mainly in the Eastern sector air masses advection from SE, E and $\mathrm{NE}$ directions. At the same time "extremely cold stress" 
(category -5 ) and categories -3 and -2 were observed in the anticyclonic circulation with air advection from the SE with a frequency of $1.3 \%$. Piotrowski (2008), in his research for the Łódź agglomeration, also notes that during the Winter the lowest values of UTCI occurred as the most frequent in case of radiative weather conditions during the high-pressure system over Poland whereas higher values of UTCI are related to the circulation carrying the increase in cloudiness and in air temperature with advection of air from West and South-West. During Spring and Autumn, the strong cold stresses category was noticed but with much lower frequency for advection from NW and NE direction (Spring 3\%) and SE, NW, N (Autumn 4\%). Previous studies of the authors (Rozbicka and Rozbicki, 2016a, b) concerning the influence of biometeorological stimuli of air pressure in relation to atmospheric circulation in Warsaw in regard of atmospheric circulation confirm that the atmospheric pressure changes mainly during the Winter with the anticyclonic circulation air advection from the NE direction and cyclonic circulation air mass advection from the N, NE and NW and 0 direction affect strongest on stimuli of air pressure changing. This shows the complex impact of various weather factors interacting on the human senses. Błażejczyk (2002) in his research proved that the polar continental air mass in Winter and arctic air mass in the Spring flow is the reason of extremely cold conditions. During the summer, there was no case of severe stress in the cold stress category.

The other strong kind of stress in the category, heat stress appears more rarely. The strongest load of humans by the heat (in amount categories 2 and 3 strong heat stress and very strong heat stress) occurred during the summer for anticyclonic and unclassifiable circulation (7.7\%) air masses advection with the South and South-East (S, SE and 0) direction. An important feature of the biothermal conditions of the Warsaw agglomeration is an impairment of the conditions during the summer months (Błażejczyk 2002). The reason for this situation is the frequency of atmospheric states that are felt 'hot' or even 'very hot'. Both high air temperature and high intensity of solar radiation consist for this. Błażejczyk (2002) states that high index values UTCI are caused by the appearance of tropic air over Poland and also continental polar air masses in the Summer and in the Spring.

In addition, the special attention should be drawn to the appearance of the conditions of category 2 strong heat stress in the spring with the highest frequency $(3.2 \%)$ for unclassifiable circulation with air advection from direction 0 . In the Autumn the strong heat stress appeared only once $(0.2 \%)$ at cyclonic circulation air advection from the NE direction. The category 4 extreme heat stress was not recorded in the analysed period.

Biothermal conditions were also studied by Bryś and Ojrzyńska (2016). Although the work concerns Wroclaw-a city located in the warmest region of Poland-the results of their work are similar to the results of this study. The strongest strain of the human in amount categories $2,3,-3,-4$ and -5 were recorded for unclassifiable circulation air advection from the SE direction. In the annual course strong cold stress, very strong cold stress and extreme cold stress occurred more frequently than the strong and very strong heat stresses. Similarly to this study, the strain of strong heat stresses appeared with air mass advection from the south direction than strong cold stresses with air advection from the SE direction.

\subsection{Detailed characteristics of selected scorching hot and freezing cold days}

At the subsequent stage of the study, the longest and the most strenuous series of scorching hot days $\left(t_{\max } \geq 30{ }^{\circ} \mathrm{C}\right)$ of a heat wave (3-16 August 2015) and freezing cold days $\left(t_{\min } \leq-10{ }^{\circ} \mathrm{C}\right)$ of a cold wave (1-11 February 2012) were selected for detailed analysis (Fig. 6).

\subsubsection{The heat wave (3-16 August 2015)}

On the selected hot days, the air temperature ranged from $17{ }^{\circ} \mathrm{C}$ at night and in the morning to as much as $36^{\circ} \mathrm{C}$ during the day. This corresponds to bioclimatic conditions of UTCI values ranging from favourable (no thermal stress), category $0-51.2 \%$, through categories 1 and 2 (moderate to strong heat stress), both occurring with a similar frequency of 23.5 and $24.4 \%$, respectively, to instances of very strong heat stress (category 3 ), with the observed frequency of $0.9 \%$. From 3 August 2015 until 12 August 2015 , the air temperature exceeding $30{ }^{\circ} \mathrm{C}$ continued nearly throughout the day, with the maximum $11 \mathrm{~h}$ (10:00-21:00) on 7-8 August (Fig. 6). A very strong heat stress (category 3 ) only occurred on 8 August with a frequency of $12.5 \%$, whereas on both days ( 7 and 8 August) a strong heat stress (category 2) was observed with a high frequency of $45.8 \%$ (7 August) and 25\% (8 August). A moderate heat stress accounted for $12.5 \%$ on 7 August and $33.3 \%$ on 8 August. On both days the favourable conditions of no thermal stress occurred with a frequency of $41.7 \%$ ( 7 August) and 29.2\% (8 August). During the heat wave of 3-16 August 2015, a well-developed highpressure system prevailed over Warsaw-an anticyclone with air masses coming mainly from S and SE-which did not change until the end of the heat wave that is on 15/16 August, when an easterly cyclonic circulation took over. The persistent high-pressure system caused little cloudiness often below 4 oktas (0-8) and thus unrestricted influx of solar radiation which reached high values, up to and exceeding $700 \mathrm{~W} \mathrm{~m}^{-2}$ at the time. The relative humidity was low, especially during the day, with a minimum of $16 \%$. The wind speed usually did not exceed $4 \mathrm{~m} \mathrm{~s}^{-1}$. 


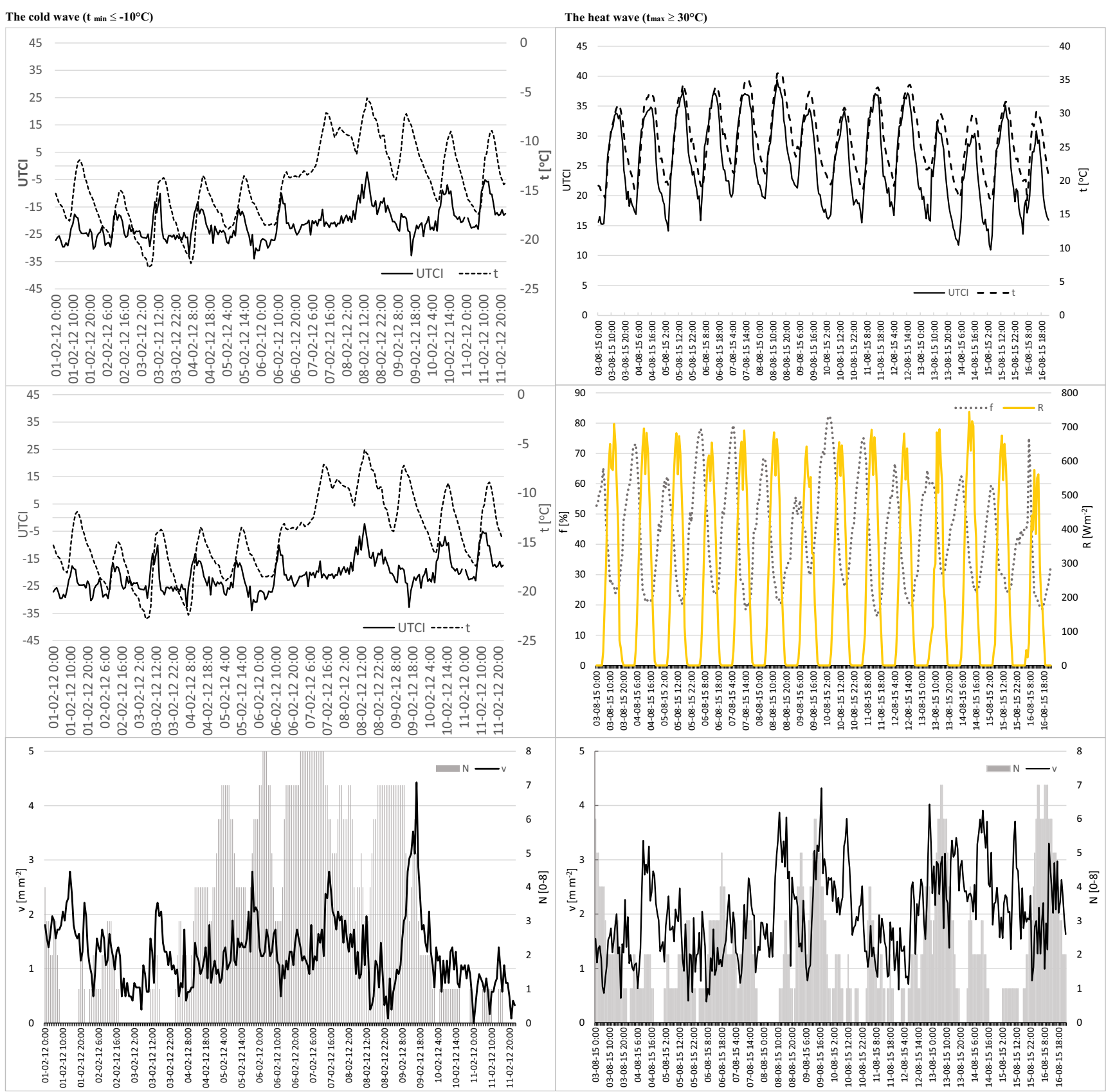

Fig. 6 Hourly course of UTCI values and selected meteorological elements for cold wave (1-11 February 2012) and heat wave (3-16 August 2015) in Warsaw-Ursynow

\subsubsection{The cold wave (1-11 February 2012)}

The second period subject to a detailed analysis was the series of days of a cold wave $\left(t_{\min } \leq-10^{\circ} \mathrm{C}\right)$ which took place from 1 February 2012 to 11 February 2012. On the studied freezing cold days, the air temperature ranged from $-23{ }^{\circ} \mathrm{C}$ at night and in the morning to $-5{ }^{\circ} \mathrm{C}$ during the day, but only in several instances. Such a temperature pattern corresponds to bioclimatic conditions (UTCI) ranging from a moderate cold stress (category -2$)-9.1 \%$, to a strong cold stress (category -3 ), which occurred with a frequency of as much as $78 \%$, to a very strong cold stress (category -4 ) with a considerable frequency of $12.9 \%$.

On most of these days, the air temperature of $-10{ }^{\circ} \mathrm{C}$ or below was maintained nearly all day, and the coldest day, with the temperature remaining below $-15{ }^{\circ} \mathrm{C}$ for $24 \mathrm{~h}$, was 2 February (Fig. 6). On that day, only two unfavourable conditions prevailed of a strong cold stress (category -3 ) in as many 
as $83 \%$ of cases and of a very strong cold stress (category -4) in $16.7 \%$ of cases (Fig. 6). During the cold wave of 1-11 February 2012, a high-pressure system prevailed over Warsaw - an anticyclone with air masses coming mainly from the SE (1-5 Feb) and E (6-11 Feb). That allowed a free influx of solar radiation, whose values reached up to and exceeding $400 \mathrm{~W} \mathrm{~m}^{-2}$ at a relatively small cloud amount, whose mean value was approximately 3 oktas $(0-8)$. The relative humidity ranged from below $50 \%$ ( $8 \mathrm{Feb}$ ), mainly during the day, to more than $80 \%$; the wind speed was low and did not exceed $4 \mathrm{~m} \mathrm{~s}^{-1}$ (Fig.6).

Analysis of the hourly UTCI values course for heat and cold wave against the weather determinants showed they occurred in the same types of circulation and the inflow of air from the direction of the S, E and SE. It is confirmed that the most common occurrence of such situations, which were discussed in the previous 'Section 3.2'. In the case of anticyclonic circulation, solar factor plays the most important role in shaping air temperature and the dynamic factor-slight wind not exceeding the velocity $4 \mathrm{~m} \mathrm{~s}^{-1}$.

\subsubsection{Summary}

As demonstrated by Błażejczyk (2004), Kuchcik et al. (2013) and Mackosza (2013), the time which offers the most favourable thermal conditions for leisure and recreation in Poland, including the analysed area of South Warsaw, is the period from around the 20th day of April to the 10th day of October. That is when the prevailing synoptic situations which do not put much thermal stress on the human body occur with a frequency of $42.9 \%$ in October to $66.6 \%$ in August.

In summer months, the values fluctuated dramatically from $-4{ }^{\circ} \mathrm{C}$ (moderate cold stress) to approx. $40{ }^{\circ} \mathrm{C}$ (very strong heat stress). Weather conditions which cause strong and very strong heat stresses were relatively uncommon. In the summer, in about $5 \%$ of cases the very strong heat stress conditions occurred (category 2), whereas in the winter, only $0.6 \%$ instances of a very strong cold stress (category -4) were observed, absent in the other seasons. The most favourable conditions (no thermal stress) were ascertained in $61 \%$ of cases in the summer, in $42 \%$ of cases in the spring and autumn and only $0.9 \%$ of cases in the winter. Similar results were obtained by Kuchcik et al. (2013) for Warsaw (1991-2000), where conditions of a strong and very strong heat stress (UTCI $>32{ }^{\circ} \mathrm{C}$ ), found in the summer months (June through August) with the highest frequency of $10.5 \%$ in July, which is comparable to the results obtained in this study $(8.4 \%$ in July). On the other hand, the conditions in which the human body is exposed to a strong and very strong cold stress (UTCI $<-13{ }^{\circ} \mathrm{C}$ ), which Kuchcik et al. (2013) found to have occurred from October to April with the highest frequency of $44.4 \%$ in January, in this study occurred with a lower frequency of $32.3 \%$ (January). The period considered in this study
(1998-2015) is a continuation of the period analysed by Kuchcik et al. (2013) (1991-2000), so there is a similarity of the frequency of occurrence of strong and very strong heat stresses; however, the strong and very strong cold stresses seem to follow a downward trend.

The analysis of selected most strenuous days of the heat wave (3-16 August 2015) and the cold wave (1-11 February 2012) confirmed the occurrence of a high frequency of conditions stressing the human body with strong and very strong heat (up to about $45 \%$ of strong heat stress cases, category 2) as well as strong cold (up to $78 \%$ of strong cold stress cases, category 3 ) for most of the day. The exceptionally long heat wave (14 days) and cold wave (11 days) in Warsaw were connected with anticyclonic atmospheric circulation from the $\mathrm{S}$ in the case of the heat wave and the SE in both cases.

Summarizing the impact of atmospheric circulation on thermal loads (thermally acceptable) be stated that the most favourable type of circulation is anticyclonic circulation with the highest average occurrence up to $96 \%$ of cases in categories $1,0,-1$ and -2 . Simultaneously the anticyclonic circulation gives the highest occurrence of extreme heat loads (that is, categories 2 and 3 ) with an average of $7 \%$. While the load cold stress was recorded at unclassifiable circulation over $42 \%$ of cases. Based on the obtained results, it can be stated that the southern part of Warsaw-Ursynów representing residential district is a place favourable for life. This is indicated by a large share of the situation with the lack of heat loads and insignificant appearance of extreme thermal loads, under certain conditions circulation.

Open Access This article is distributed under the terms of the Creative Commons Attribution 4.0 International License (http:// creativecommons.org/licenses/by/4.0/), which permits unrestricted use, distribution, and reproduction in any medium, provided you give appropriate credit to the original author(s) and the source, provide a link to the Creative Commons license, and indicate if changes were made.

\section{References}

Basarin B, Lukić T, Matzarakis A (2016) Quantification and assessment of heat and cold waves in Novi Sad, Northern Serbia. Int J Biometeorol 60:139-150

BioKlima (n.d.) ver.2.6 Polish Academy of Sciences, Department of Geoecology and Climatology. www.igipz.pan.pl/bioklima.html . Accessed 5 June 2016

Błażejczyk K (2002) Znaczenie czynników cyrkulacyjnych i lokalnych w kształtowaniu klimatu i bioklimatu aglomeracji warszawskiej (in Polish). Dokumentacja Geograficzna 26 IGiPZ PAN, 160

Błażejczyk K (2004) Bioclimatic principles of recreation and tourism in Poland (in Polish). PAN IGiPZ Warsaw, Geographical Studies 192: 291

Błażejczyk K, Błażejczyk A (2014) Assessment of bioclimatic variability on regional and local scales in central Europe using UTCI. Scientific Annals of "Alexandru Ioan Cuza" University of IASI. Vol. LX. no.I, s.II c.Geography series 2014: 67-82

Błażejczyk K, Bröede P, Fiala D, Havenith G, Holmer I, Jendritzky G, Kampmann B, Kunert A (2010) Principles of the new Universal Thermal Climate Index (UTCI) and its application to bioclimatic research in European scale. Miscellanea Geographica 14:91-102 
Błażejczyk K, Epstein Y, Jendritzky G, Staiger H, Tinz B (2012) Comparison of UTCI to selected thermal indices. Int J Biometeorol 56:515-535

Błażejczyk K, Jendritzky G, Bröde P, Fiala D, Havenith G, Epstein Y, Psikuta A, Kampmann B (2013) An introduction to the Universal Thermal Climate Index (UTCI). Geogr Pol 86(1):5-10

Błażejczyk K, Kuchcik M, Błażejczyk A, Milewski P, Szmyd J (2014) Assessment of urban thermal stress by UTCI - experimental and modelling studies: an example from Poland. Erde 145(1-2):16-33

Bleta A, Nastos PT, Matzarakis A (2014) Assessment of bioclimatic conditions on Crete Island, Greece. Reg Environ Chang 14:1967-1981

Bröde P, Krüger EL, Rossi FA, Fiala D (2012a) Predicting urban outdoor thermal comfort by the Universal Thermal Climate Index UTCI- a case study in Southern Brazil. Int J Biometeorol 56:471-480

Bröde P, Fiala D, Blazejczyk K, Holmer I, Jendritzky G, Kampmann B, Tinz B, Havenith G (2012b) Deriving the operational procedure for the Universal Thermal Climate Index (UTCI). Int J Biometeorol 56:481-494

Bryś K, Ojrzyńska H (2016) Stimulating qualities of biometeorological conditions in Wrocław (in Polish). Acta Geographica Lodziensia 104:193-200

Chabior M (2011) Selected aspects of the bioclimate of Szczecin (in Polish). Prace i studia Geograficzne 47:293-300

Coutts AM, White EC, Tapper NJ, Beringer J, Livesley SJ (2016) Temperature and human thermal comfort effect of street trees across three contrasting street canyon environments. Theor Appl Climatol 124:55-68. doi:10.1007/s00704-015-1409-y

Czarnecka M, Mąkosza A, Nidzgorska-Lencewicz J (2011) Variability of meteorological elements shaping biometeorological conditions in Szczecin, Poland. Theor Appl Climatol 104(1-2), 101-110

Czarnecka M, Nidzgorska-Lencewicz J (2014) Intensity of urban heat island and air quality in Gdańsk during 2010 Heat Wave, pol. J Environ Stud 23(2):329-340

Fiala D, Havenith G, Brode P, Kampmann B, Jendritzky G (2012) UTCI Fiala multi-node model of human heat transfer and temperature regulation. Int J Biometeorol 56:429-441

Fröhlich D, Matzarakis A (2015) A quantitative sensitivity analysis on the behavior of common thermal indices under hot and windy conditions in Doha,Qatar. Theor Appl Climatol. doi:10.1007/s00704-015-1410-5

Havenith G, Fiala D, Blazejczyk K, Richards M, Brode P, Holmer I, Rintamaki H, Benshabat Y, Jendritzky G (2012) The UTCI clothing model. Int J Biometeorol 56:461-470

Idzikowska D (2011) Relationship between mortality and UTCI in Paris, Rome, Warsaw and Budapest (in Polish). Prace i Studia Geograficzne 47:311-318

Jacobs S, Pezza A, Barras V, Bye J (2014) A new 'bio-comfort' perspective for Melbourne based on heat stress, air pollution and pollen. Int J Biometeorol 58:263-275

Kotas P, Twardosz R, Nieckarz Z (2013) Variability of air mass occurrence in southern Poland (1951-2010). Theor Appl Climatol 114:615-623

Kuchcik M., Błażejczyk K., Szmyd J., Milewski P., Błażejczyk A., Baranowski J. (2013) Potencjał leczniczy klimatu Polski (in Polish) IGiPZ PAN Wydawnictwo Akademickie Sedno, Warsaw

Kyselỳ J (2002) Probability estimates of extreme temperature events: stochastic modeling approach vs. extreme value distributions. Stud Geophys Geod 46:93-112

Kyselỳ J (2004) Mortality and displaced mortality during heat waves in the Czech Republic. Int J Biometeorol 49:91-97

Lin T-P, Matzarakis A (2008) Tourism climate and thermal comfort in Sun Moon Lake, Taiwan. Int J Biometeorol 52:281-290

Lindner K (2011) Assessment of sensible climate in Warsaw using UTCI (in Polish). Prace i Studia Geograficzne 47:285-291

Lityński J (1969) Liczbowa klasyfikacja typów cyrkulacji i typów pogody dla Polski (in Polish). Pr. PIHM 97:3-15

Majewski G, Przewoźniczuk W, Kleniewska M (2014) The effect of urban conurbation on the modification of human thermal perception, as illustrated by the example of Warsaw (Poland). Theor Appl Climatol 116(1):147-154

Makkosza A (2013) Bioclimatic conditions of the Lubuskie Voivodeship. Geogr Pol 86(1):37-46

Makrogiannis T, Balafoutis Ch, Pytharoulis I (2008) The heat waves over Balkans as an indicator of the climate change: a case study on August 2006. in: Maheras P, Zanis P, Anagnostopoulou C et al.(eds) Proceedings of the $9^{\text {th }}$ Conference of Meteorology, Climatology and Atmospheric Physics. Thessaloniki, Greece 417-423

Matzarakis A (2014) Transfer of climate data for tourism applicationsthe climate tourism/transfer-information-scheme. Sustain Environ Res 24(4):273-280

Ndetto EL, Matzarakis A (2015) Urban atmospheric environment and human biometeorological studies in Dar es Salaam, Tanzania. Air Qual Atmos Health 8:175-191

Matzarakis A, Nastos PT (2011) Human-biometeorological assessment of heat waves in Athens. Theor Appl Climatol 105:99-106

Matzarakis A, Rammelberg J, Junk J (2013) Assessment of thermal bioclimate and tourism climate potential for central Europe - the example of Luxembourg. Theor Appl Climatol 114:193-202

Nemeth A (2011) Changing thermal bioclimate in some Hungarian cities. Acta Climatologica Chorologica. Universitatis Szegediensis, T 44 45: 93-101

Nidzgorska-Lencewicz J (2015) Variability of human-biometeorological conditions in Gdańsk. Pol J Environ Stud 24(1):215-226

Nidzgorska-Lencewicz J, Makosza A (2013) Assessment of bioclimatic conditions within the area of Szczecin agglomeration. Meteorol Z 22(5):1-14

Nowosad M, Rodzik B, Wereski S, Dobek M (2013) The UTCI index in Lesko and Lublin and its circulation determinants. Geogr Pol 86(1): 29-36

Okoniewska M, Więcław M (2013) Long-term variability of bioclimatic conditions in the second half of the 20 century at noon hours in Poland based on Universal Thermal Climate Index. Journal of Health Sciences 3(15):116-131

Pianko-Kluczyńska K (2007) New calendar of types atmospheric circulation by J. Lityński (in Polish). Wiad Met Hydr Gosp Wod I 4:65-85

Piotrowski P (2008) Daily variability of thermal sensations on urban and rural areas in relations to atmospheric circulation (in Polish). In: Kłysik K, Wibig J, Fortuniak K (ed) Climate and Bioclimate Cities, pp 537-549

Quansheng G, Qinqin K, Jianchao X, Jingyun Z (2016) Application of UTCI in China from tourism perspective. Theor Appl Climatol. doi: 10.1007/s00704-016-1731-z

Report on tourism visitors to Warsaw (2016) (in Polish). Analysis on the base Ipsos Loyalty - The Customer and Employee Research Specilists. http://www.um.warszawa.pl/o-warszawie/warszawa-wliczbach/ruch-turystyczny. Accessed 4 Jan 2017

Rozbicka K, Rozbicki T (2016a) The 'Weekend Effect' on Ozone in the Warsaw Conurbation, Poland. Pol J Environ Stud 25(4):1675-1683

Rozbicka K, Rozbicki T (2016b) The influence of biometeorological stimuli of air pressure in relation to atmospheric circulation in Warsaw (in Polish). Acta Sci Pol, Formatio Circumiectus 15(3): $121-136$

Rozbicka K, Majewski G, Rozbicki T (2014) Seasonal variation of air pollution in Warsaw conurbation. Meteorol Z 23(2):175-179

Szyga-Pluta K (2009) Circulation types and cloud genera in Poznań (in Polish). Bad.Fizjogr nad Polską Zach. t 60 seria A: 133-145

Walikewitz N, Jänicke B, Langner M, Endlicher W (2015) Assessment of indoor heat stress variability in summer and during heat warnings: a case study using the UTCI in Berlin, Germany. Int J Biometeorol. doi:10.1007/s00484-015-1066-y

Zaninović K, Matzarakis A (2009) The bioclimatological leaflet as a means conveying climatological information to tourists and the tourism industry. Int J Biometeorol 53:369-374 